\title{
Foodborne Pathogens Recovered from Ready-to-Eat Foods from Roadside Cafeterias and Retail Outlets in Alice, Eastern Cape Province, South Africa: Public Health Implications
}

\section{Mirriam E. Nyenje ${ }^{1}$, Collins E. Odjadjare ${ }^{1}$, Nicoline F. Tanih ${ }^{1}$, Ezekiel Green ${ }^{1}$ and Roland N. Ndip ${ }^{1,2, *}$}

1 Department of Biochemistry and Microbiology, Faculty of Science and Agriculture, University of Fort Hare, PMB X1314, Alice 5700, South Africa;

E-Mails: nyenjem@yahoo.com (M.E.N.); ecodjadjare@yahoo.com (C.E.O.); nicofriline@yahoo.com (N.F.T.); egreen@ufh.ac.za (E.G.)

2 Department of Microbiology and Parasitology, Faculty of Science, University of Buea, P.O. Box 63, Buea, Cameroon

* Author to whom correspondence should be addressed; E-Mail: ndip3@yahoo.com; Tel.: +27-782-696-191; Fax: +27-866-247-59.

Received: 24 April 2012; in revised form: 21 May 2012 / Accepted: 10 July 2012 / Published: 27 July 2012

\begin{abstract}
This study assessed the microbiological quality of various ready-to-eat foods sold in Alice, South Africa. Microbiological analysis was conducted on 252 samples which included vegetables, potatoes, rice, pies, beef and chicken stew. The isolates were identified using biochemical tests and the API 20E, API 20NE and API Listeria kits; results were analyzed using the one-way-ANOVA test. Bacterial growth was present in all the food types tested; high levels of total aerobic count were observed in vegetables, $6.8 \pm 0.07$ followed by rice, $6.7 \pm 1.7$ while pies had the lowest count $(2.58 \pm 0.24)$. Organisms isolated included: Listeria spp. (22\%), Enterobacter spp. (18\%), Aeromonas hydrophila (12\%), Klebsiella oxytoca (8\%), Proteus mirabilis (6.3\%), Staphylococcus aureus (3.2\%) and Pseudomonas luteola (2.4\%). Interestingly, Salmonella spp. and Escherichia coli were not isolated in any of the samples. There was a statistically significant difference $(p<0.05)$ in the prevalence of foodborne pathogens from hygienic and unhygienic cafeterias. The results indicated that most of the ready-to-eat food samples examined in this study did not meet bacteriological quality standards, therefore posing
\end{abstract}


potential risks to consumers. This should draw the attention of the relevant authorities to ensure that hygienic standards are improved to curtain foodborne infections.

Keywords: street foods; microbial quality; foodborne pathogens; bacterial count; South Africa

\section{Introduction}

Foodborne diseases are an increasingly recognized problem involving a wide spectrum of illnesses caused by bacterial, viral, parasitic or chemical contamination of food. Although viruses account for half of all the foodborne illnesses, most hospitalizations and deaths related to foodborne infections are due to bacterial agents. Diarrheal diseases are the commonest manifestation of food poisoning and in some cases, can lead to death. The diseases are caused by either toxin from the "disease-causing" microbe, or by the human body's reactions to the microbe itself [1].

Street sold foods are appreciated for their unique flavors and convenience. They also assure food security for low income urban population and livelihood for a significant proportion of the population in many developing countries [2]. However, the unhygienic conditions in which these foods are prepared, stored and served raise a question regarding their microbiological quality. Researchers have investigated the microbiological quality of street vended foods in different countries; high bacterial counts and a high incidence of foodborne pathogens in such foods have been reported. In Ghana, bacterial counts of 5.13-6.36 $\log _{10} \mathrm{CFU} \mathrm{g} \mathrm{g}^{-1}$ were documented in the street foods of Kumasi [3]. Another study in Accra reported a total bacterial count range of $0.8-6.3 \log _{10} \mathrm{CFU} \mathrm{g} \mathrm{g}^{-1}$, Enterobacteriaceae count of 0.3-4.7 $\log _{10} \mathrm{CFU} \mathrm{g} \mathrm{g}^{-1}$ and $0.3-3.7 \log _{10} \mathrm{CFU} \mathrm{g}$ of Staphylococcus aureus [4]. In Egypt, Ismail [5] studied the microbial quality of ready-to-eat meat sandwich and reported aerobic plate counts, Enterobacteriaceae, and Enterococci counts range of $2 \times 10^{3}-4 \times 10^{6}$, $6 \times 10-8 \times 10^{2}$ and $3 \times 10^{3}-6 \times 10^{5} \mathrm{CFU} \mathrm{g}^{-1}$ respectively.

Contamination of food by enteric pathogens can occur from the farm if human sewage is used to fertilize the soils or if sewage water is used to irrigate the crops. Such risks are further increased if the food is mishandled during processing and preparations where pathogens could multiply exponentially under favorable conditions [2]. However, no study has been conducted on the microbial quality of the food supplied by local food establishments in Alice. Therefore, the present study was carried out to assess the microbiological quality of various ready-to-eat foods supplied in Alice, in a bid to throw more light on the inherent risk associated with such foods.

\section{Results and Discussion}

\subsection{Bacterial Count of Isolates in the Food Samples}

The mean bacterial count of the isolates in the food samples were expressed as $\log _{10} \mathrm{CFU} \mathrm{g}^{-1}$ for easy computation. Food were classified as acceptable if the bacterial count was less than or equal to $5 \log _{10} \mathrm{CFU} \mathrm{g} \mathrm{g}^{-1}$ [6]. The mean value of aerobic bacterial count on vegetables, rice, potatoes, beef, chicken stew and pies were $6.8 \pm 0.07,6.7 \pm 1.7,6.27 \pm 0.18,5.32 \pm 3.14,6.05 \pm 0.12$ and 
$2.58 \pm 0.24 \log _{10}$ CFU g ${ }^{-1}$ respectively (Table 1). The bacterial count of vegetables, rice, potatoes, beef and chicken stew was statistically significant when compared with pies $(p<0.05)$. A similar comparison was made for food from hygienic and unhygienic sources; the results revealed that there was statistically significant difference in the bacterial load of beef stew and rice from hygienic and unhygienic cafeterias $(p<0.05)$. However, no significance was observed for vegetables, chicken and potatoes samples $(p>0.05)$ (Table 2$)$.

Plate count of aerobic mesophilic microorganisms found in food is one of the microbiological indicators for food quality. The presence of aerobic organisms reflects existence of favorable conditions for the multiplication of microorganisms. In this study, all the sample types tested had mean contamination levels of $\geq 5.0 \log _{10} \mathrm{CFU} \mathrm{g} \mathrm{g}^{-1}$ except the pies. The New South Wales (NSW) Food Authority [6] recommends the standard limit for bacterial count of fully cooked ready-to-eat foods to be $<5.0 \log _{10} \mathrm{CFU} \mathrm{g}{ }^{-1}$. Hence these foods could be of high risk in transmitting enteric pathogens. These findings corroborate previous works [4,7,8]. In their study, Mensah et al. [4] found a bacterial count of $6.3 \pm 0.78$ in salads sold on the streets of Accra. Likewise, Christison et al. [8] also reported high bacterial prevalence in filled baguettes and salads.

Vegetables had the highest bacterial count, of 6.3-6.8 $\log _{10} \mathrm{CFU} \mathrm{g}^{-1}$. The findings are in agreement with other studies in Egypt, Turkey and Taiwan. Saddik et al. [9] reported the upper limit of $6.69 \log _{10} \mathrm{CFU} \mathrm{g} \mathrm{g}^{-1}$ aerobic counts of microorganisms on minimally processed vegetable samples in Egypt while Fang et al. [10] reported an aerobic plate count on salad vegetable samples in Taiwan ranging from 3.30-8.64 $\log _{10} \mathrm{CFU} \mathrm{g} \mathrm{g}^{-1}$. Furthermore, Vural and Erkan [11] in Turkey had a range of aerobic plate counts from 6.43 to $7.63 \log _{10} \mathrm{CFU} \mathrm{g}{ }^{-1}$.

Vegetables have been associated with foodborne outbreaks in many countries; they may be contaminated from the farm with human sewage, and from the irrigation water. Unsafe water used for rinsing the vegetables and sprinkling to keep them fresh are other possible sources of contamination [7]. As most of these produce are eaten raw or with minimal cooking, their microbial content may represent a risk factor for the consumer's health [12]. Some of these factors might be the possible source of contamination in the vegetables under study. A study in Morocco, reported the occurrence of pathogenic bacteria mostly of the Enterobacteriaceae family in vegetables irrigated by untreated wastewater. Although usually regarded as human pathogens, members of this family have also been recognized as inhabitants of soil and plants. Thus, vegetables may serve as a reservoir from which these bacteria can colonize and infect a susceptible host [13].

Worthy of note is the fact that unhygienic cafeterias registered high bacterial counts; lack of sources of running water, refrigeration facilities, and post production operations and personal hygiene of the food handlers might be the possible contributing factors. It was also observed that in the unhygienic shops, vendors washed the utensils and dishes used for preparation and serving their food in buckets containing unclean water which were likely not replaced throughout the whole day. This might also be another reason for cross-contamination. 
Table 1. Mean bacterial counts of the food samples examined.

\begin{tabular}{|c|c|c|c|c|c|c|c|c|}
\hline \multirow[t]{2}{*}{ Food types } & \multirow{2}{*}{$\begin{array}{c}\text { Bacterial count range } \\
\left(\log _{10} \mathrm{CFU} \mathrm{g} \mathrm{g}^{-1}\right) \\
\end{array}$} & \multirow{2}{*}{$\begin{array}{l}\text { Mean bacterial count } \\
\left.\left(\log _{10} \mathrm{CFU} \mathrm{g}\right)^{-1}\right) \pm \mathrm{SD}\end{array}$} & \multicolumn{6}{|c|}{$p$-value } \\
\hline & & & $\mathbf{V}$ & $\mathbf{R}$ & C & B & PT & $\mathbf{P}$ \\
\hline Vegetables $(n=42)$ & $6.3-6.8$ & $6.8 \pm 0.07$ & - & 0.235 & 0.913 & 0.001 & 0.585 & 0.000 \\
\hline Rice $(n=42)$ & $4.3-6.7$ & $6.7 \pm 1.7$ & 0.235 & - & 0.196 & 0.000 & 0.513 & 0.000 \\
\hline Chicken stew $(n=42)$ & $5.9-6.2$ & $6.05 \pm 0.12$ & 0.913 & 0.196 & - & 0.001 & 0.513 & 0.000 \\
\hline Beef stew $(n=42)$ & $3.9-6.15$ & $5.32 \pm 3.14$ & 0.001 & 0.000 & 0.001 & - & 0.000 & 0.000 \\
\hline Potatoes $(\mathrm{n}=42)$ & $6.0-6.4$ & $6.27 \pm 0.18$ & 0.585 & 0.513 & 0.513 & 0.000 & - & 0.000 \\
\hline Pies $(n=42)$ & $2.30-2.81$ & $2.58 \pm 0.24$ & 0.000 & 0.000 & 0.000 & 0.000 & 0.000 & - \\
\hline
\end{tabular}

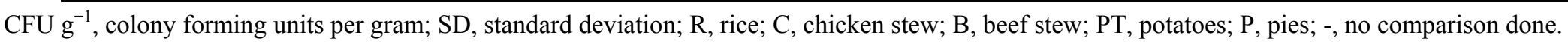

The mean difference is considered significant at $p<0.05$.

Table 2. Mean bacterial counts of food obtained from hygienic and unhygienic cafeterias.

\begin{tabular}{lccc}
\hline \multirow{2}{*}{ Food types } & \multicolumn{2}{c}{ Bacterial count $\left(\log _{\mathbf{1 0}} \mathbf{c f u} / \mathbf{g}\right) \pm$ Standard deviation } & \multirow{2}{*}{$\boldsymbol{p}$-value } \\
\cline { 2 - 3 } & Unhygienic & Hygienic & $0.128(>0.05)$ \\
Vegetables $(\mathrm{n}=42)$ & $6.8 \pm 0.07$ & $6.4 \pm 0.7$ & $0.000(<0.05)$ \\
Rice $(\mathrm{n}=42)$ & $6.7 \pm 1.7$ & $6.35 \pm 0.07$ & $0.122(>0.05)$ \\
Chicken stew $(\mathrm{n}=42)$ & $6.05 \pm 0.12$ & $5.95 \pm 0.07$ & $0.002(<0.05)$ \\
Beef stew $(\mathrm{n}=42)$ & $5.32 \pm 3.14$ & $4.32 \pm 3.01$ & $0.171(>0.05)$ \\
Potatoes $(\mathrm{n}=42)$ & $6.27 \pm 0.18$ & $6.15 \pm 0.21$ & ND \\
Pies $(\mathrm{n}=42)$ & ND & $3.9 \pm 0.7$ & \\
\hline
\end{tabular}

CFU $\mathrm{g}^{-1}$, colony forming units per gram; ND, not determined; unhygienic cafeterias, vending sites without running water, toilets, fridges to store food and dirt environment; hygienic cafeterias, vending sites with running water, clean food preparation surfaces, toilets, clean environment and food handlers who comply with food hygienic standards. The mean difference is considered significant at $p<0.05$. 


\subsection{Prevalence of Foodborne Pathogens in the Various Food Types}

Table 3 depicts the occurrence of possible pathogens in the 252 food samples tested. Bacterial growth was observed in all the food types; the most prevalent bacteria were Listeria spp. (22\%), Enterobacter spp. (18\%), Aeromonas hydrophilla (12\%), Klebsiella oxytoca (8\%) and Proteus mirabilis (6.3\%). Vegetables and rice had the highest level of contamination with $108(18 \%)$ isolates each. Listeria ivanovii was prevalent in pies (33\%) followed by chicken $(28 \%)$ while beef, rice and potatoes registered 14\% each. Enterobacter cloacae was mainly isolated from beef stew (24\%), pies and chicken (17\%) each and rice 14\%. Aeromonas hydrophila was detected in $10(24 \%)$ of the vegetables, seven $(17 \%)$ of rice and six $(14 \%)$ of potatoes. Klebsiella oxytoca was present in seven $(17 \%)$ of pies and potatoes, and in six (14\%) of vegetables. It was also observed that the prevalence of the pathogens in the environment varied as Proteus mirabilis was isolated from seven (17\%) of rice, four $(10 \%)$ of chicken and three $(7 \%)$ of beef obtained from one of the university cafeterias while none was isolated from the other shops. Interestingly, E. coli and Salmonella spp. which are common food pathogens were not isolated. The prevalence of foodborne pathogens from hygienic and unhygienic cafeterias was also compared. The unhygienic cafeterias recorded the highest number of isolates 339 (54\%) compared to 299 (47\%) from hygienic cafeterias (Figure 1). However, L. ivanovii and $P$. mirabilis were the only isolates which were recovered more from unhygienic cafeterias than hygienic cafeteria.

Figure 1. Bacterial contamination of food from hygienic and unhygienic cafeterias.

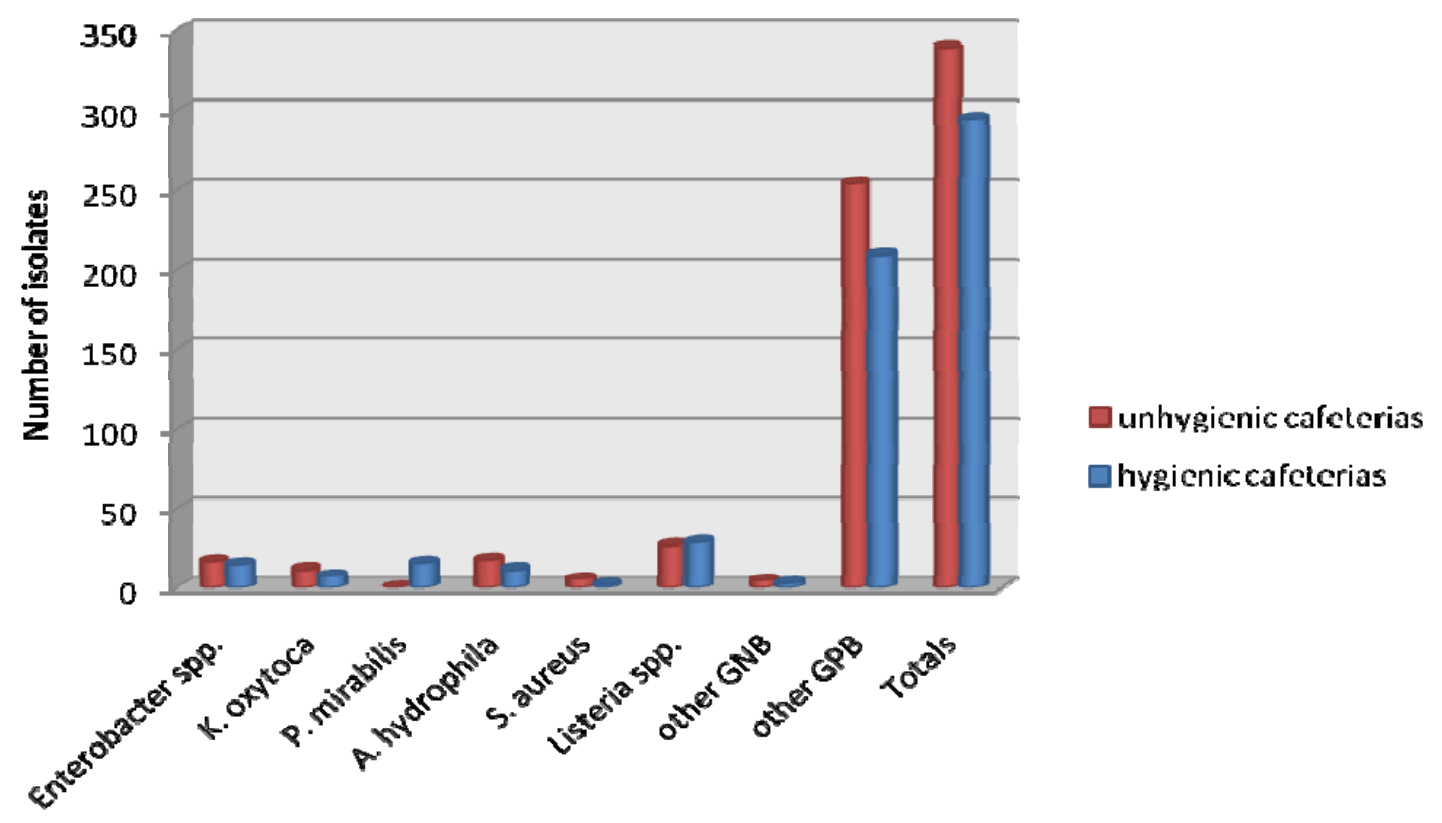

Isolated arganisms

Legend: GNB, Gram negative bacilli; GPB, Gram positive bacilli. 
Table 3. Bacteria distribution in the various food samples examined.

\begin{tabular}{lccccccc}
\hline Bacteria isolates & $\begin{array}{c}\text { Chicken stew } \\
(\mathbf{n}=\mathbf{4 2})\end{array}$ & $\begin{array}{c}\text { Beef stew } \\
(\mathbf{n}=\mathbf{4 2})\end{array}$ & $\begin{array}{c}\text { Vegetables } \\
(\mathbf{n = 4 2 )}\end{array}$ & $\begin{array}{c}\text { Rice } \\
(\mathbf{n}=\mathbf{4 2})\end{array}$ & $\begin{array}{c}\text { Potatoes } \\
(\mathbf{n = 4 2 )}\end{array}$ & $\begin{array}{c}\text { Pies } \\
(\mathbf{n}=\mathbf{4 2})\end{array}$ & Number (\%) occurrence \\
\hline Listeria ivanovii & 11 & 6 & 8 & 6 & 6 & 14 & $51 / 252(20 \%)$ \\
Listeria grayi & 1 & 0 & 1 & 1 & 1 & 1 & $5 / 252(2 \%)$ \\
Enterobacter cloacae & 7 & 10 & 2 & 6 & 3 & 7 & $35 / 252(14 \%)$ \\
Enterobacter sakazaki & 1 & 0 & 4 & 0 & 1 & 0 & $6 / 252(2.4)$ \\
Enterobacter gergoviae & 0 & 0 & 0 & 0 & 0 & 2 & $2 / 252(1 \%)$ \\
Enterobacter cancerogenus & 0 & 0 & 1 & 0 & 1 & 1 & $3 / 252(1.2 \%)$ \\
Proteus mirabilis & 4 & 3 & 2 & 7 & 0 & 0 & $16 / 252(6.3 \%)$ \\
Klebsiella oxytoca & 2 & 2 & 6 & 1 & 7 & 3 & $21 / 252(8.3 \%)$ \\
Aeromonas hydrophila & 2 & 4 & 10 & 7 & 6 & 0 & $30 / 252(12 \%)$ \\
Staphylococcus aureus & 1 & 0 & 0 & 2 & 3 & 2 & $8 / 252(3.2 \%)$ \\
Pantoea spp. & 0 & 3 & 2 & 0 & 2 & 0 & $7 / 252(2.8 \%)$ \\
Pseudomonas luteola & 0 & 1 & 2 & 1 & 0 & 2 & $6 / 252(2.4 \%)$ \\
Other Gram positive Bacilli & 54 & 62 & 70 & 77 & 64 & 66 & $267 / 588(45 \%)$ \\
Total isolates & $\mathbf{8 5}$ & $\mathbf{9 3}$ & $\mathbf{1 0 8}$ & $\mathbf{1 0 8}$ & $\mathbf{9 4}$ & $\mathbf{1 0 0}$ & $\mathbf{5 8 8}$ \\
\hline
\end{tabular}


The study found that ready-to-eat foods from roadside cafeterias contained more organisms if compared to that sold in standard fast foods centres and supermarkets which had running water and cement floors. Bukar et al. [7] found that ready-to-eat rice sold on the streets of Kano contained more microorganisms if compared to that sold in standard fast food centres. The road side cafeterias had no running water, hands and utensils washing was done in one bucket where the water was not regularly changed. This coupled with unhygienic surroundings like sewage, improper waste disposal system, might be the possible sources of food contamination in these sites.

Members of the family Enterobacteriaceae have been considered a potent cause of foodborne outbreaks [14]. In this study, Enterobacteriaceae represented $46 \%$ of the isolates. Enterobacter cloacae (14\%) was the most prevalent among the isolated Enterobacteriaceae. The findings concurs the work of Falomir et al. [12] who found Enterobacter cloacae and Klebsiella oxytoca, to be the most prevalent coliforms in ready-to-eat-salads served in the dining halls of a pre-school and a primary school in Valencia city, Spain. Enterobacter spp. are the sixth most common cause of nosocomial infection in particular, Enterobacter cloacae have been implicated in a broad range of clinical syndromes. The literature is replete with descriptions of bacteraemia, meningitis, urinary tract infection, septicaemia, wound infection, central nervous system and gastrointestinal tract infections [2]. Therefore the presence of these organisms in the foods under study might pose a health risk to children and individuals with underlying conditions.

Listeria species has been associated with a wide variety of food sources particularly poultry, red meat and meat products [15]. The present study recorded a high occurrence of Listeria spp. in pies (33\%) and chicken stew (28\%). These findings are in line with those of other authors [15-17]. In Egypt, Listeria contamination rate in meat and chicken products was reported to be $41 \%$ [15], lower than the $73.9 \%$ reported in Malaysia from imported frozen beef [18] and 83.3\% from raw minced meat in Turkey [17]. The bacteria can be endemic in food processing environments, because it survives food-processing technologies that rely on acidic or salty conditions and, unlike many pathogens, can continue to multiply slowly at low temperatures, allowing for growth even in properly refrigerated foods. Hence, their presence may be indicative of poor hygiene or cross contamination, which is considered to be a possible source of Listeria contamination in processed meat [19]. In addition, minced/chopped meat products by their nature, undergo extensive processing and handling during their production thereby increasing the risk of contamination. This might explain the high prevalence of L. ivanovii in pies which were of either minced/chopped chicken or red meat.

Nevertheless, despite the high rates of contamination of certain foods with Listeria species, listeriosis is a relatively rare disease as compared with other common foodborne illnesses. However, because of its high case fatality rate of approximately $20-30 \%$, listeriosis has been ranked second, after salmonellosis as the most frequent cause of foodborne infection-related deaths in Europe [19].

Clinical manifestations of listeriosis range from febrile gastroenteritis to more severe invasive forms, including sepsis, meningitis, rhombencephalitis and perinatal infections. Perinatal listeriosis can lead to abortion, birth of a stillborn fetus or a baby with generalized infection (granulomatosis infant-septica), and sepsis or meningitis in the neonate [20].

Listeria monocytogenes is the most common causative agent of human listeriosis. However, L. ivanovii, an animal pathogen has been previously isolated, although rarely, from infected humans, 
indicating pathogenic potential for humans [20]. Therefore the isolation of L. ivanovii in the present study might reflect a health risk to the consumers particularly pregnant women.

The study registered a low Proteus mirabilis occurrence of $6.3 \%$. It is noteworthy that all 16 isolates were obtained from one source (one of the university shops). Proteus mirabilis is a proteolytic bacterium implicated in food deterioration and spoilage. In addition to opportunistic infections, it can also cause food poisoning when consumed in contaminated food such as meat, vegetables, and seafood [21].

Staphylococcus aureus was prevalent in $3.2 \%$ of the samples. The results were contrary to the findings of Ghosh et al. [2] and Kumar et al. [22] who reported high prevalence of Staphylococcus aureus in street-vended foods. Differences in geographical location and personal hygiene of the food handlers might help to explain this discrepancy. In their study, Ghosh et al. [2] reported high prevalence of Staphylococcus aureus from coriander sauce 91 (60\%) and 129 (86\%) from ready-to-eat salads in India. The authors attributed this high prevalence to poor hygienic conditions of the premises due to rubbish, sewage and other noxious substances present in the vicinity. Kumar et al. [22] presented the high staphylococcal count from fruit chaat (a drink made from a mixture of fruits and vegetables) samples obtained from mobile vendors without any covering compared to those samples from mobile vendors with coverings. The authors suggested that, covering to some extent acts as a shield for air borne bacterial pathogens.

Staphylococcus species are found on the skin and in the nose and throat of most healthy people; they are also widespread in untreated water, raw milk and sewage. When Staphylococcus aureus is allowed to grow in foods, it can produce a toxin that causes illness. Although, cooking destroys the bacteria, the toxin produced by Staphylococcus aureus is heat stable and may not be destroyed even by heating, let alone by refrigeration. Foods that are handled frequently during preparation are prime targets for Staphylococci contamination [23].

The prevalence of $A$. hydrophila was at $12 \%$ with the organism isolated more from vegetables $(10 / 42)$ than in the other food types. Other studies reported a prevalence of $4 \%, 26 \%$ and $41 \%$ Aeromonads in dairy products, vegetables and sea foods respectively [24,25]. Although A. hydrophila is water based, waterborne outbreaks have not been reported, and waterborne transmission has not been well established as various studies have been unsuccessful in linking patient isolates of A. hydrophila with isolates recovered from the water supply [26,27]. Nevertheless, this bacterium has gained public health recognition as an opportunistic pathogen. It has been implicated as a potential agent of gastroenteritis, septicaemia, cellulitis, colitis, and meningitis, and is frequently isolated from wound infections sustained in aquatic environments [28,29]. Palumbo et al. [30] found Aeromonas isolates universally present in all foods tested, including sea-foods, raw milk, chicken, and meats such as lamb, veal, pork, and ground beef.

\section{Experimental Section}

\subsection{Study Area}

Alice is a rural settlement in the Nkonkobe municipality of the Eastern Cape province of South Africa and situated in the geographical coordinates $32^{\circ} 50^{\prime} 36^{\prime \prime} \mathrm{S}, 26^{\circ} 55^{\prime} 00^{\prime \prime} \mathrm{E}$; with a population of about 9,788 and a student population of 8,548 [31]. The study was conducted between August and 
November, 2011. Two university restaurants and eight ready-to-eat food vending sites in Alice Town were sampled. These sites were chosen because they are very popular among students, workers, commuters, shoppers and passers-by. Members of these groups buy food from at least one of these out lets at one time or the other. They include two garages that were designated (G1 and G2), three supermarkets (S1, S2 and S3), four roadside cafeterias and two university restaurants (C1, C2, C3, C4, C5 and C6). The sites were classified as unhygienic cafeterias if they had no running water, poor hygienic conditions of the staff and surrounding i.e., rubbish, sewage and other noxious substances present in the vicinity that can attract foodborne vectors such as flies, whereas hygienic cafeterias were termed those with running water, clean food preparation surfaces, toilets, clean environment and food handlers who comply with food hygienic standards. CAC/GL 22R [32], defined food hygiene as all conditions and measures necessary to ensure the safety and suitability of food at all stages.

\subsection{Sample Collection}

A total of 252 cooked samples were purchased comprising of 42 batches of six food types which included beef and chicken stew, potatoes, rice, vegetables and pies all of which are popular foods from cafeterias in the study area. Samples were packed separately and transported to the Microbial Pathogenicity and Molecular Epidemiology Research Laboratory of the University of Fort Hare for immediate processing.

\subsection{Bacteriological Analysis of the Samples}

\subsubsection{Sample Preparation, Culture and Bacterial Count}

Samples were prepared according to the method of Akoachere et al. [33] with some modifications. Twenty five grams of each sample was weighed and homogenized by blending in $225 \mathrm{~mL}$ of sterile buffered peptone water. One millilitre of the homogenate was introduced into $9 \mathrm{~mL}$ of the buffered peptone water in a test tube, labelled 1:10 $\left(10^{-1}\right)$ dilution and serially diluted to five other test tubes labelled $10^{-2}, 10^{-3}, 10^{-4}, 10^{-5}$ and $10^{-6}$; the procedure was repeated for each sample and the blender was carefully cleaned and disinfected in between samples to prevent any cross contamination. One hundred microliters of each of the diluted sample was plated on Nutrient agar. The plates were incubated aerobically for $24 \mathrm{~h}$ at $37{ }^{\circ} \mathrm{C}$. All discrete colonies were counted where possible and expressed as the $\log _{10}$ of colony forming units per gram $\left(\mathrm{CFU} \mathrm{g} \mathrm{g}^{-1}\right)$. To improve recovery and detection, the tubes were incubated aerobically at $37{ }^{\circ} \mathrm{C}$ for $12-24 \mathrm{~h}$ after which a loopful of enrichment broth was cultured on Salmonella/Shigella, Mac Conkey, Eosin-Methylene Blue (EMB) and Colombia blood agar (Oxoid, Basingstoke, England) supplemented with 5\% horse blood. The plates were incubated aerobically for $24-48 \mathrm{~h}$ at $37^{\circ} \mathrm{C}$.

\subsubsection{Isolation and Biochemical Characterization of the Isolates}

Colonies were presumptively identified by colony pigmentation and Gram staining characteristics. Pure cultures were obtained by streaking a portion of an isolated colony on nutrient agar and incubated aerobically at $37^{\circ} \mathrm{C}$ for $24 \mathrm{~h}$. The isolates were confirmed by oxidase, catalase, and coagulase activity. Isolates were further characterized biochemically using API 20E whilst API 20NE was used for the 
identification of non-fastidious and non-enteric Gram negative rods. The confirmation of Listeria spp. was carried out using API Listeria kit (Biomerieux, Marcy-L'etoile, France). The tests were performed according to manufacturer's instruction for use. Briefly, a single colony from young cultures (18-24 h) was emulsified in $5 \mathrm{~mL}$ of sterile sodium chloride $(0.85 \%)$ and the turbidity adjusted to the equivalent of the turbidity of $0.5 \mathrm{McF}$ arland standards. The standardized bacterial suspension was distributed into the tubes of the test strip carefully to avoid the formation of bubbles. Anaerobiosis was created by overlaying with sterile mineral oil; the strips were then incubated in humid atmosphere for 18-24 h at $37{ }^{\circ} \mathrm{C}$. Data interpretation was performed using the Analytical profile index (API) database (V4.1) with the apiweb ${ }^{\mathrm{TM}}$ identification software.

\section{Statistical Analysis}

Statistical analysis was performed using excel and SPSS version 19. The bacterial counts were expressed as mean \pm Standard deviation using excel. One way ANOVA followed by Turkey's post hoc test was used to compare the bacterial counts in various food types and bacterial count from hygienic and unhygienic cafeterias. The mean difference was considered significant at $p<0.05$.

\section{Conclusions}

These findings demonstrate that ready-to-eat food sold in Alice Town constitutes a likely potential hazard to human health. The isolation of Enterobacteriaceae in ready-to-eat foods that are fully cooked is a good indicator of post-processing contamination or inadequate cooking. Therefore access to running water and health education to the vendors on personal hygiene, food safety and proper disposal of waste would improve food quality thereby reducing food borne incidences.

\section{Acknowledgments}

The authors are thankful to the Govan Mbeki Research and Development Centre, University of Fort Hare for their funding.

\section{Conflict of Interest}

The authors declare no conflict of interest.

\section{References}

1. Teplitski, M.; Wrigh, A.C.; Lorca, G. Biological approaches for controlling shellfish-associated pathogens. Curr. Opin. Biotechnol. 2009, 20, 185-190.

2. Ghosh, M.; Wahi, S.; Kumar, M.; Ganguli, A. Prevalence of enterotoxigenic Staphylococcus aureus and Shigella spp. in some raw street vended Indian foods. Int. J. Environ. Health Res. 2007, 17, 151-156.

3. Feglo, P.; Sakyi, K. Bacterial contamination of street vending food in Kumasi, Ghana. J. Med. Biomed. Sci. 2012, 1, 1-8.

4. Mensah, P.; Yeboah-Manu, D.; Owusu-Darko, K.; Ablordey, A. Street foods in Accra, Ghana: How safe are they? WHO Bull. 2002, 80, 546-554. 
5. Ismail, S.A. Microbiological quality of hawawshy consumed in Ismailia, Egypt. J. Food Saf. 2006, 26, 251-263.

6. NSW Food Authority. Microbiological Quality Guide for Ready-To-Eat Foods: A Guide to Interpreting Microbiological Results. Available online: http:/www.foodauthority.nsw.gov.au/_ Documents/science/microbiological_quality_guide_for_RTE_food.pdf (accessed 22 May 2012).

7. Bukar, A.; Uba, A.; Oyeyi, T.I. Occurrence of some enteropathogenic bacteria in some minimally and fully processed ready-to-eat foods in Kano metropolis, Nigeria. Afr. J. Food Sci. 2010, 4, $32-36$.

8. Christison, C.A.; Lindsay, D.; von Holya, A. Microbiological survey of ready-to-eat foods and associated preparation surfaces in retail delicatessens, Johannesburg, South Africa. J. Food Control 2008, 19, 727-733.

9. Saddik, M.F.; El-Sherbeeng, M.R.; Bryan, F.L. Microbiological profiles of Egyptian raw vegetables and salads. J. Food Protect. 1985, 48, 883-886.

10. Fang, T.J.; Wei, Q.K.; Liao, C.W.; Hang, M.J.; Wang, T.H. Microbiological quality of 18 degrees ready-to-eat food products sold in Taiwan. Int. J. Food Microbiol. 2003, 80, 241-250.

11. Vural, A.; Erkan, M.E. Investigation of microbial quality of some leafy green vegetables in Turkey. J. Food Technol. 2008, 6, 285-288.

12. Falomir, M.P.; Gozalbo, D.; Rico, H. Coliform Bacteria in Fresh Vegetables: From Cultivated Lands to Consumers. In Current Research, Technology and Education Topics in Applied Microbiology and Microbial Biotechnology; Formatex Research Center: Badajoz, Spain, 2010; pp. 1175-1181.

13. Karamoko, Y.; Ibenyassine, K.; Ennaji, M.M.; Anajjar, B.A.; Mhand, R.; Chouibani, M. Bacterial pathogens recovered from vegetables irrigated by waste water in Morocco. J. Environ. Health 2007, 17, 221-230.

14. Centinkaya, F.; Cibik, G.; Soyuteniz, E.; Ozkin, C.; Kayali, R.; Levent, B. Shigella and Salmonella contamination in various foodstuffs in Turkey. J. Food Control 2008, 19, 1059-1063.

15. El-Malek, A.M.A.; Ali, S.F.H.; Hassanein, R.; Moemen, A.M.; Elsayh, K.I. Occurrence of Listeria species in meat, chicken products and human stools in Assiut city, Egypt with PCR use for rapid identification of Listeria monocytogenes. Vet. World 2010, 3, 353-359.

16. Molla, B.; Yilma, R.; Alemayehu, D. Listeria monocytogenes and other Listeria species in retail meat and milk products in Addis Ababa, Ethiopia. Ethiop. J. Health Dev. 2004, 18, 208-212.

17. Yucel, N.; Citak, S.; Onder, M. Prevalence and antibiotic resistance of Listeria species in meat products in Ankara, Turkey. Food Microbiol. 2005, 22, 241-245.

18. Hassan, Z.; Endang, P.E.; Abdul, R.S.R.; Rusul, G. Prevalence of Listeria species and L. monocytogenes in meat and fermented fish in Malaysia. Southwest Asian J. Trop. Med. Publ. Health 2001, 32, 99-108.

19. Watson, R. Deaths from listeriosis remains a cause for concern in Europe. BMJ 2009, doi: 10.1136/bmj.b319.

20. Allerberger, F.; Wagner, M. Listeriosis: A resurgent foodborne infection. Clin. Microbiol. Infect. 2010, 16, 16-23. 
21. Braide, W.; Oranusi, S.; Udegbunam, L.I.; Oguoma, O.; Akobondu, C.; Nwaoguikpe, R.N. Microbiological quality of an edible caterpillar of an emperor moth, Bunaea alcinoe. J. Ecol. Nat. Environ. 2011, 3, 176-180.

22. Kumar, M.; Agarwal, D.; Ghosh, M.; Ganguli, A. Microbiological safety of street vended fruit chats in Patiala city. Indian J. Med. Microbiol. 2006, 24, 75-76.

23. Ghosh, M.; Mudgil, S.; Ganguli, A. Microbiological quality of carrots used for preparation of fresh squeezed street vended carrot juices in India. J. Food Agric. Environ. 2004, 2, 143-145.

24. Neyts, K.G.; Huy, S.M.; Swings, J.; Debevere, J. Incidence and identification of mesophilic Aeromonas species from retail foods. Lett. Appl. Microbiol. 2000, 31, 359-361.

25. Mcmahon, M.A.S.; Wilson, I.G. The occurrence of enteric pathogens and Aeromonas species in organic vegetables. Int. J. Food Microbiol. 2001, 70, 155-162.

26. World Health Organization (WHO). Food Safety and Foodborne Illness. Available online: http://www.who.int/mediacentre/factsheets/fs237/en/ (accessed on 30 October 2011).

27. Borchardt, M.A.; Bertz, P.D.; Spencer, S.K.; Battigelli, D.A. Incidence of enteric viruses in groundwater from household wells in Wisconsin. Appl. Environ. Microbiol. 2003, 69, 1172-1180.

28. Krovacek, K.; Faris, A.; Baloda, S.B.; Lindberg, T.; Peterz, M.; Mansson, I. Isolation and virulence profiles of Aeromonas spp. from different municipal drinking water supplies in Sweden. Int. J. Food Microbiol. 1992, 9, 215-222.

29. Gavriel, A.A.; Landre, J.P.B.; Lamb, A.J. Incidence of mesophilic Aeromonas within a public drinking water supply in north-east Scotland. J. Appl. Microbiol. 1998, 84, 383-392.

30. Palumbo, S.A.; Maxino, F.; Williams, A.C.; Buchanan, R.L.; Thayer, D.T.W. Starch-ampicillin agar for the quantitative detection of Aeromonas hydrophila. Appl. Environ. Microbiol. 1985, 50, 1027-1030.

31. Alice Regeneration Programme: High Level Feasibility Assessment Report. Available online: http://www.aspire.org.za/reports/Alice\%20Regeneration\%20-\%20High\%20Level\%20Feasibility \%20Assessment\%20-\%20Final.pdf (accessed on 5 March 2012).

32. Regional Guidelines for the Design of Control Measures for Street-Vended Foods (Africa). Available online: http://www.google.com.hk/url? sa=t\&rct=j\&q=Regional+Guidelines + for + the + Design + of + Control + Measures + for + Street-Vended + Foods\&source $=$ web\& $c d=1 \& v e d=0$ CFMQFjA A\&url $=$ http $\% 3 \mathrm{~A} \% 2 \mathrm{~F} \% 2 \mathrm{Fwww}$.codexalimentarius.org\%2Finput $\% 2 \mathrm{Fdownload} \% 2 \mathrm{Fstandards} \% 2 \mathrm{~F}$ 350\%2FCXG_022Re.pdf\&ei=B8UMUMX1KeqNiAeU4bW2DQ\&usg=AFQjCNFq5gAoo6ZZo mVws5kRSSRR9WGrKw\&cad=rjt (accessed on 1 June 2012).

33. Akoachere, J.-F.T.K.; Bughe, R.N.; Oben, B.O.; Ndip, L.M.; Ndip, R.N. Phenotypic characterization of human pathogenic bacteria in fish from the coastal waters of South West Cameroon: Public health implications. Rev. Environ. Health 2009, 24, 147-155.

(C) 2012 by the authors; licensee MDPI, Basel, Switzerland. This article is an open access article distributed under the terms and conditions of the Creative Commons Attribution license (http://creativecommons.org/licenses/by/3.0/). 